\title{
Assessing Technical Drawing Proficiency in the Strengthened Technical Vocational-Education Program (STVEP)
}

\author{
Domenic T. Sanchez ${ }^{1, *}$, Larry B. Peconcillo Jr. ${ }^{1}$, Rumuela L. Wong ${ }^{1}$, \\ Emerson D. Peteros ${ }^{2}$, Julie Anne T. Godinez ${ }^{3}$ \\ ${ }^{1}$ Cebu Technological University NEC, City of Naga, Cebu, Philippines \\ ${ }^{2}$ Cebu Technological University, Main Campus, Cebu City, Philippines \\ ${ }^{3}$ Cebu Technological University, Cebu City Mountain Campus, Cebu City, Philippines
}

Received July 26, 2020; Revised September 3, 2020; Accepted October 24, 2020

\section{Cite This Paper in the following Citation Styles}

(a): [1] Domenic T. Sanchez, Larry B. Peconcillo Jr., Rumuela L. Wong, Emerson D. Peteros, Julie Anne T. Godinez, "Assessing Technical Drawing Proficiency in the Strengthened Technical Vocational-Education Program (STVEP)," Universal Journal of Educational Research, Vol. 8, No. 12A, pp. 7282 - 7295, 2020. DOI: 10.13189/ujer.2020.082511.

(b): Domenic T. Sanchez, Larry B. Peconcillo Jr., Rumuela L. Wong, Emerson D. Peteros, Julie Anne T. Godinez (2020). Assessing Technical Drawing Proficiency in the Strengthened Technical Vocational-Education Program (STVEP). Universal Journal of Educational Research, 8(12A), 7282 - 7295. DOI: 10.13189/ujer.2020.082511.

Copyright $\bigcirc 2020$ by authors, all rights reserved. Authors agree that this article remains permanently open access under the terms of the Creative Commons Attribution License 4.0 International License

\begin{abstract}
The K-12 curriculum prepares students with the technical knowledge and skills requirements for various opportunities of the 21st century, thus exploring the identified profile variables and the perception of the Technical Drawing competencies in preparation for the Technical Vocational training courses intended for respondents. A descriptive method approach was employed, and a close-ended type of questionnaire to gather data from Grade 9 student respondents selected using random sampling. The findings reveal a significant relationship between some of the students' perceptions of technical drawing competencies and the identified profile variables, such as the students' perception of the adequacy of strongly linked facilities to mensuration, freehand drawing, lettering, construct geometric figures and construct pictorial drawing competencies. Gender is well associated with freehand drawing, specifically among female respondents, while the final grade was correlated with their perception of freehand drawing and mensuration competencies. The result led to the rejection of the null hypothesis. However, some of the competencies which have no significant relationship with the identified profile variables according to the perception of the respondents could be an interesting gap to conduct further research to those who are currently taking the technical drawing as the Grade 7 and 8 students for a different set of perceptions of
\end{abstract}

same competencies. Students' perception of competencies is considered vital to efficiently enhance the teaching methodologies, content, and logistics necessary to deliver Technical Drawing learning competencies.

Keywords: Perception, Competencies, Technical Drawing, Technical-Vocational Education

\section{Introduction}

The encompassing goal of the K-12 Curriculum is the holistic development of every student with the skills of the 21st century for work, entrepreneurship, development of middle-level skills, and higher education [22]. Training in specialized vocational education is essential to fine-tune students' success and expertise concerning the skills needs of the 21st century. The technical drawing is a prerequisite for the technical training courses offered in Technical Vocational Education under the STVEP curriculum. Technical drawing, such as Drafting Technology, provides students the opportunity to learn the skills required by today's high-tech engineering, architecture, and manufacturing industries, Sira [10]. That aptitude for spatial visualization could be improved in Technical 
Drawing. As suggested by Adanez \& Velasco [14], spatial visualization aptitude may be considered an efficiency indicator of the teaching-learning process in acquiring drawing skills. Therefore, the training process must be tenaciously maintained with the utmost importance to acquire necessary technical knowledge and skills, Azodo[16]. The research explores the coherence of profile variables identified with the students' perception of technical drawing competencies. It should be remembered that the basic principle of vocational education is habit psychology when a set of habits is practiced out of the habit explained by Wood[1]. Habits as a repeated practice product can only be significant if they are not transformed into a specific capability type. This behavior can also be linked to Dr. Charles A. Prosser's position on the value of systematic education, which is the sixth principle of technical education. It points out that vocational education, in tandem with the intended training experience, effectively develops correct behavior and thinking patterns replicated to the point where such habits are guided to an optimum degree that is valid and conscientious-productive. Any productive effort or self-productivity may be the consequence of an ideal perception. Students' perception of their competence or skills is considered essential because it is based on their previous sensory input impression. On the other hand, the perception of these impressions of sensations is influenced by the awareness and experience based on Simons' study [2]. Perception has to do with the desire to acquire different skills. How the senses have identified produces sensation by doing so. Thus, if the experience satisfies the senses, the student's learning interest is maximized. It concerns Thorndike's Law of Readiness, which refers to the training provided by a person for learning by Singh[3]. When a person is unwilling to respond and is pressured to do so, this interaction may cause frustration and irritation. In other words, learning interest results from a good impression of maximizing the perception of experience. However, one thing is right; a teacher has a significant influence on students' success. Marks and Louis[4] proposed a relationship between teacher control that could include classroom teaching and monitoring school objectives and students' academic success. The problem with the teacher-factor in the field of instruction is real. Improved teacher performance in optimal student performance, according to Uddin \& Nwachokor[9]. Competence is infectious, especially for young people who often imitate the performer, which is why superheroes have a definite impact on children's lives. On the other hand, teachers' educational qualification and effectiveness have so much to contribute to the learning process and academic metamorphosis that learners' low performance is attributed directly to the weak educational competence, Kalule et al.[5] whereas developed competencies were vital and related to future employment, requiring technical knowledge and skills, Sira et al.[11]. The statement of
Shulruf et al.[6] affirms the value of mental capacity and the preparation for assessing school students' level of achievement, representing academic success or failure. The study's context may be broadened from the following perspectives: To the administrators, the study may provide clear information and background of the technical drawing subject according to the existing curriculum in terms of general planning, implementation, and improvement of teaching strategies and school facilities. This study's findings may improve teaching methods and approaches from which future proposals could be formulated to correlate students' educational need for technical knowledge and skills to the technical drawing teachers. Parents are partners of the educational thrust; therefore, this study would encourage them to morally and financially support their children enrolled in the program.

\subsection{Research Problem}

The study assessed the technical drawing proficiency of students enrolled in the Strengthened Technical Vocational-Education Program and sought to respond to the following:

a. The students' profile in terms of age and gender, final grade in technical drawing, and combined family income?

b. The students' perception as to:

b.1. performance in technical drawing competencies as to:

b.1.1. mensuration,

b.1.2. freehand drawing,

b.1.3. lettering,

b.1.4. construct geometric figures,

b.1.5. orthographic projection, and

b.1.6. construct pictorial drawing, and

b.2. adequacy of drawing facilities/equipment, tools, and materials?

c. Is there a significant relationship between students' perception of competence in technical drawing and the profile variables?

\subsection{Statement of Hypothesis}

a. $\mathrm{H}_{0}$ : There is no significant relationship between students' perception of competence in technical drawing and the profile variables.

\section{Method}

A descriptive method was used, along with the objective-random sampling, to gather data from 100 Grade 9 student respondents enrolled in the STVEP curriculum who had previously taken the Technical Drawing subject. These students were admitted in the STVEP curriculum after passing admission requirements, such as interviews 
and written exams to ensure their fitness as to the I.Q., level of interest, understanding of 'learning by doing' and the potential goal that may be achieved through obtaining the required technical knowledge, and skills of technical drawing. The study's purpose was explained in depth to the selected students, as they would provide essential data that would be academically and institutionally beneficial, particularly to the technical drawing.

The close-ended type of questionnaire was pilot-tested to ensure its validity and was used to collect data. All data were considered relevant but confidential and exclusive for statistical purposes. The collected data were subject to statistical analysis, such as percentages, to establish the respondents' status of profile variables. Mean was used to determine the respondents' level of perception concerning the enumerated variables in the study. ANOVA was used to establish the significance between the perception of the respondents on competencies and profile variables. The perceptions on competencies and availability of technical drawing facilities/equipment, tools, and materials were given appropriate verbal interpretations using the five-point scale with the corresponding weights and range.

Table 1. Perception of the Technical Drawing Competencies

\begin{tabular}{|c|c|c|c|}
\hline Weight & Range & $\begin{array}{c}\text { Level of } \\
\text { Perception }\end{array}$ & Description \\
\hline 5 & $4.21-5.00$ & Easy & $\begin{array}{c}\text { If the competency is } \\
\text { not difficult }\end{array}$ \\
\hline 4 & $3.41-4.20$ & Moderate & $\begin{array}{c}\text { If the competency is } \\
\text { less difficult }\end{array}$ \\
\hline 3 & $2.61-3.40$ & Average & $\begin{array}{l}\text { If the competency is } \\
\text { slightly difficult }\end{array}$ \\
\hline 2 & $1.81-2.60$ & Hard & $\begin{array}{c}\text { If the competency is } \\
\text { difficult }\end{array}$ \\
\hline 1 & $1.00-1.80$ & Very Hard & $\begin{array}{l}\text { If the competency is } \\
\text { extremely difficult }\end{array}$ \\
\hline
\end{tabular}

Table 2. Perception of Facilities/Equipment, and Tools and Materials

\begin{tabular}{cccc}
\hline Weight & Range & $\begin{array}{c}\text { Level of } \\
\text { Perception }\end{array}$ & Description \\
\hline 5 & $4.21-5.00$ & $\begin{array}{c}\text { Very Much } \\
\text { Adequate }\end{array}$ & $\begin{array}{c}\text { If there is more than } \\
\text { what is needed } \\
\text { If there is just enough } \\
\text { for what is needed } \\
\text { If there is enough for } \\
\text { what is needed } \\
\text { If you have any but } \\
\text { not enough }\end{array}$ \\
1 & $2.61-3.40$ & Adequate & $\begin{array}{c}\text { In-adequate } \\
\text { If it is non-existent }\end{array}$ \\
\hline
\end{tabular}

\section{Result and Discussion}

The survey's student respondents' demographic characteristics showed a gender distribution of 40 males and 60 females who are students of a public secondary school. Of the 100 respondents, the age range is from 14 to 18. Among male respondents, 8 (20\%) were 16 year-old, 30 (75\%) were 15 year-old, and 2 (5\%) 14 year-old. Among female respondents, 1 (1.70\%) 18-year old, 2
(3,20\%) 17-year old, 7 (11.70) 16-year old, 40 (66.70) 15 -year old, and 10 (16.70) 14 year-old. The total mean age is 15.10 , while most of the student respondents were 15 years of age, comprising 70.00 of the population, considered the exact school age for Grade 9 students, composed of 30 or $75.00 \%$ male and 40 or 66.70 female.

In terms of the combined monthly family income, $4 \%$ of respondents have a combined monthly family income of Php30,000.00-above, 7\% affirmed to have a monthly income of Php 20,000.00-29,999.00, 12\% is earning Php15,000.00-19,999.00 monthly. Furthermore, 8\% takes home the monthly income of Php10,000.00-14,999.00, while $28 \%$ to having a monthly income of Php5,000.00-9,999.00, and 23\% earns roughly Php3,000.00-4,999.00 per month. Twelve percent admit the Php1,000.00-2,999.00 monthly income, and 6\% whose family combined monthly income is Php1,000-below.

In terms of mensuration, the respondents perceived 5 units of competency as easy. These can be enumerated as 1.) write measurement on drawing, 2.) secure required measuring tool(ruler), 3.) measure object/distance in Inch, 4.) measure distance/object in centimeter, 5.) measure object/distance in millimeter. The total weighted Mean for mensuration is 4.51, interpreted as easy. [20,21]

On the other hand, 8 units of competency in Freehand Drawing were perceived as easy by the student respondents, which can be enumerated as 1.) draw long and short horizontal lines, 2.) draw long and short vertical lines, and 3.) sharpen a pencil, 4.) erase pencil lines, 5.) draw borderline, 6.) draw long and short perpendicular, 7.) draw long and short inclined lines, and 8.) draw long and short parallel lines. The respondents perceived the following 2 units of competency in Freehand Drawing as moderate like 9.) draw arcs and circles, and 10.) draw objects in outline form. The total weighted Mean for Freehand Drawing is 4.47, interpreted as easy.

Furthermore, 9 competencies in lettering were perceived as moderate, which can be enumerated as 1.) maintain inter letter spacing, 2.) maintain interword spacing, 3.) center title using "scratch-paper method," 4.) print lowercase single-stroke letters, 5.)center title using "trial-and-error method," 6.) print uppercase single-stroke gothic letters, 7.) print single-stroke gothic numbers, and ampersand, 8.)print word/s in single-stroke gothic letter style, and 9.) print paragraph in single-stroke gothic letter style. Lettering has a total weighted mean of 3.95 , interpreted as moderate. [20,21]

The respondents perceived 7 units of competency in Construct Geometrical Figures as easy such as 1.) draw square, 2.) bisect horizontal and vertical lines, 3.) draw pentagon, 4.) draw equilateral triangle, 5.) manipulate 30x60, and $45 \times 45$ triangles, 6.) bisect common angles, and 7.) draw hexagon. In addition, the respondents considered the following 8 units of competency to be moderate, which can be enumerated as 9.) manipulate protractor, 10.) manipulate compass, 11.) bisect arc, 12.) draw heptagon, 
13.) draw octagon, 14.) draw nonagon, 15.) draw decagon, and 16.) draw ellipse. The total weighted Mean of Construct Geometrical Figures is 4.17, interpreted as moderate. In this particular competency, relative competencies such as Measuring, Freehand drawing, and Lettering from which students have developed skills are expected to level up. The respondents perceived 2 units of competency in Orthographic Projection as easy such as 1.) write measurement on top, front, and side views; and 2.) sketch alphabet of lines (visible line, hidden line, centerline, and the like.) $[20,21]$ While the respondents perceived the following 8 units of competency as moderate such as 1.) manipulate pencil and $45 \times 5$ triangle, 2.) block in views, 3. .) draw orthographic views of the object with horizontal and vertical surfaces, 4.) draw a detailed working sketch, 5.) draw orthographic views of the object with inclined surfaces, 6.) sketch an assembly working drawing, 7.) draw orthographic views of object with regular curve surfaces, and 8.) draw orthographic views from the given pictorial view. The total weighted Mean for Orthographic Projection is 3.91, interpreted as moderate. [20,21]

Moreover, 10 units of competency in Construct Pictorial Drawing were perceived by the respondents as moderate such as 1.) draw parallel perspective, 2.) draw angular perspective, 3.) draw isometric axes, 4.) draw isometric views of objects with horizontal and vertical surfaces, 5.) draw cabinet pictorial views, 6.) draw cavalier and cabinet axes, 7.) draw isometric views of object with incline surfaces, 8.) draw isometric view from the given orthographic views, 9.) draw isometric views of objects with regular curve surfaces, and 10.) draw cavalier pictorial views. The total weighted Mean for Construct Pictorial
Drawing is 3.67, interpreted as moderate. [20,21].

And for Technical Drawing Facilities/Equipment, Tools And Materials, based on the perception of the respondents, the following were perceived as very much adequate which can be enumerated as 1.) blackboard, 2.) drawing tables, 3.) technical drawing room, 4.) drawing stool and 5.) lighting; while those that were perceived by the student respondents as very adequate are 1.) display board, 2.) garbage receptacle, 3.) cleaning paraphernalia, 4.) ventilation, 5.) grooming corner, and 6.) water and sink. Only the comfort room was perceived as inadequate. Besides, the following tools and materials, based on the student respondents' perception, were perceived as very much adequate such as 1.) ruler, 2.) t-square, 3.) Oslo paper, 4.) drawing pencil, 5.) $45 \times 45$ triangle, 6.) $30 \times 60$ triangle, 7.) compass, 8.) sharpener, 9.) protractor, 10.) soft-white eraser, and 11.) masking tape. The total weighted Mean for Technical Drawing Facilities/Equipment And Tools And Materials is 4.19, interpreted as very adequate.

Meanwhile, in the analysis of variance, it was found that students' perception of the adequacy of technical drawing facilities was substantially related to the following perceived level of competencies in Freehand Drawing ( $r=.828, p=.001)$, (very significant), lettering ( $r=.783$, $p=.002)$, (highly significant), mensuration ( $r=.748, p=.020)$, (significant), Construct Geometric Figures $(r=.756$, $p=.013$ ), (significant), and construct pictorial drawing ( $r$ $=.732, p=042$ ). However, the orthographic projection was negligible due to unpredictable factors that need to be addressed in future studies; given the availability of requisite facilities, there appeared to be a lower level of competence concerning the respondents' perception.

Table 3. Results of ANOVA of Significant Relationship between Students' Perception of Competence in Technical Drawing and the Profile Variables

\begin{tabular}{|c|c|c|c|c|c|c|c|c|c|c|}
\hline \multirow[t]{2}{*}{$\begin{array}{c}\text { Students Perception of } \\
\text { their Technical Drawing } \\
\text { Competencies }\end{array}$} & \multicolumn{2}{|c|}{ Age } & \multicolumn{2}{|c|}{ Gender } & \multicolumn{2}{|c|}{ Final Grade } & \multicolumn{2}{|c|}{$\begin{array}{c}\text { Combined } \\
\text { Family Income }\end{array}$} & \multicolumn{2}{|c|}{$\begin{array}{l}\text { Perception of the } \\
\text { Adequacy of Tech. } \\
\text { Drawing Facilities }\end{array}$} \\
\hline & $\mathbf{R}$ & Sig & Eta & Sig & Eta & Sig & Eta & Sig & $\mathbf{R}$ & Sig \\
\hline 1. Mensuration & .198 & .430 & .022 & .832 & .334 & $.010^{*}$ & .230 & .641 & .748 & $.020^{*}$ \\
\hline 2. Freehand Drawing & .244 & .208 & .223 & $.025^{*}$ & .281 & $.048^{*}$ & .281 & .352 & .828 & $<.001 * * *$ \\
\hline 3. Lettering & .168 & .599 & .023 & .820 & .197 & .282 & .241 & .578 & .783 & $.002 * *$ \\
\hline $\begin{array}{l}\text { 4. Construct Geometric } \\
\text { Figures }\end{array}$ & .214 & .344 & .041 & .683 & .125 & .678 & .256 & .496 & .756 & $.013^{*}$ \\
\hline $\begin{array}{c}\text { 5. Orthographic } \\
\text { Projection }\end{array}$ & .121 & .843 & .060 & .551 & .141 & .585 & .311 & .213 & .705 & .120 \\
\hline $\begin{array}{l}\text { 6. Construct Pictorial } \\
\text { Drawing }\end{array}$ & .052 & .992 & .093 & .356 & .149 & .540 & .339 & .117 & .732 & $.042^{*}$ \\
\hline
\end{tabular}

* is significant ( $p$-value $<.05)$,

$* *$ is highly significant ( $p$-value $<.01)$,

*** is very highly significant ( $p$-value $<.001)$. 
Furthermore, it was also found that only the perceived competence in freehand drawing was significantly related to gender ( $e=.223, p=.025$ ), suggesting that female students believed that they were more competent in freehand drawing than male students. It is similar to Avila \& Malquisto's [12] findings that female students can equally provide services and perform practical skills, thereby attain the desired level of productivity compared with their male counterparts. However, both could fit in the workplace without one dominating over the other. The majority of female respondents in this report were 60 percent of the population. The majority of respondents are 15 years of age, of which 75.00 percent are male and 66.70 percent female, although more male respondents are 15 years of age. They were randomly chosen from the 9th grade of the STVEP curriculum to preserve the integrity and not encourage single-gender representation. Each of them had dealt with the subject of technical drawing.

The study also revealed that the academic' final grade was related to their perception of skills in freehand drawing $(e=.281, p=.048)$ and mensuration $(e=.334, p=.010)$. Such findings show that those students who are skilled in freehand drawing and measurement have high final grades. The highest grade range between 90 and 94 is chosen as a privilege for the current grade equivalent adapted by the researcher, while other peculiarities and practices indicate some of the highest possible scores.

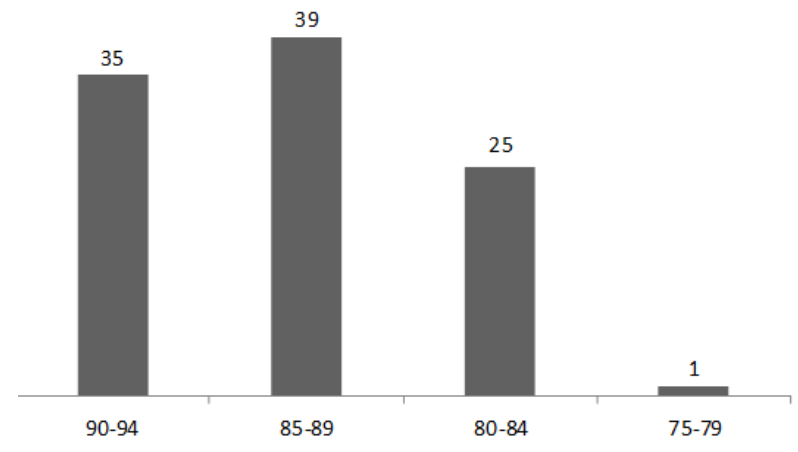

Figure 1. Final Grade in Technical Drawing

The data show that most students have earned higher grades, which could be attributed to the teacher's instructional efficacy, as supported by Uddin \& Nwachokor[9] that teaching technical drawing helps students in different technical courses. Besides, the teacher should have the enthusiasm and positive attitude to deal with them; the teaching-learning process would fail. The grading elements consist of quizzes, written unit assessments, evaluation of results, plate-making tasks, periodic examinations, and project output during the academic year. All raw scores are summarized and calculated following the criteria of the Department of Education (DepEd) for Technical Vocational Education. The K to 12 Basic Education Program uses a standard- and competency-based grading system. These are found in the curriculum guides.
Technical drawing Facilities/ Equipment, instruments, and resources, based on the perception of the respondents; as observed as very much adequate were: blackboard, drawing tables, technical drawing room, drawing stool, and lightings; whereas those perceived by the respondents as very adequate were: display board, garbage receptacle, cleaning paraphernalia, ventilation, grooming corner, and the water and sink; and lastly, the comfort room was perceived as inadequate. It must be noted that Facilities/Equipment and T-square were properties of the school monitored and maintained by the teacher who submits annual inventory reports to the school custodian for accounting, immediate repair of defects, procurement, and replacement. Much of the time, these resources have been made available to both students and subject teachers. These facilities are essential in developing the learning competencies because they are utilized during instruction and assessment of students' hands-on performance based on these competencies. Ensuring that students acquire the required competencies allows them to apply this knowledge and skills to deal with real-world experiences, as asserted by Oanh [17].

On the other hand, competent teachers teaching these skills to the students are also important because they help produce skilled graduates employed for the industry. Thus, Omar, Zahar, and Rashid [18] emphasized that vocational education in Malaysia is given primary importance to enhance the students' vocational skills as the future builders of the country. The findings also agree with the conclusion of Octavia[7] that school facilities/equipment's presence leads to an improvement in teachers' and students' performance in terms of safety, action, participation in learning, and growth in achieving success. Moses[8] described the lack of adequate funding and support of the instructional programs as one of the shortcomings in the educational system in Uganda that must be addressed right away because of its effect on the students. The presence of these facilities/equipment at school leads to improved teachers' and students' performance.

All grades were based on the weighted raw score of the learners' summative assessments. The minimum grade needed to pass a specific learning area is 60 , transmuted to 75 in the report card. The lowest mark that can appear on the report card is 60 for Quarterly Grades and Final Grades[19]. Although there is $1 \%$ among student respondents who have not yet reached the majority, it is nevertheless admissible that all of them have passed the subject. In terms of the combined parents' income, $4 \%$ of the respondents were Php30,000.00-above; this means that their parents can afford to sustain their basic needs in school, especially in technology subjects, which is more likely performance-oriented. Perhaps parents have chosen to send their children to public secondary schools, even if they can send them to private institutions to save their children's college education. $28 \%$ of parents whose 
combined monthly income ranges from Php5,000.00-9,000.00 to Php1,000.00-below still managed to send their children to school, although the number of siblings had not been identified in this study. Family basic needs are a priority, but parents have been forced to send their children to school and support them despite apparent financial constraints. Parents like them strongly believe that education is the only treasure their children can have in their lifetime.

The combined family income does not significantly impact students' perception of technical drawing competencies and the identified profile variables. However, there is evidence of a significant relationship between the majority of identified profile variables, such as gender to freehand drawing competency, final grade to freehand drawing and measuring competencies, and the adequacy of facilities/equipment to all competencies, except orthographic projection. Therefore, the null hypothesis is generally rejected. The status of other identified profile variables that have not shown a significant relationship with the respondents' perception of competencies could be an interesting gap for further research. Provided with sufficient time is available, and the respondents would be currently attending technical drawing subjects such as those in Grade 7 and Grade 8 levels who have fresh first-hand perceptions and impressions of competencies.

\section{Conclusions}

Learning is a lasting impression, a package of knowledge, skills, and values. Perceptions are the effects of a favorable impression on students based on their academic experience. This is true when it comes to evaluating teachers' performance, and the same impression could also be given as to the scale of knowing how practical the competencies of subjects are. The students' perception of technical drawing competencies was a critical factor in improving the teaching methodologies, content, and logistics needed to ensure that learning delivery would reach a certain level of the K-12 program's competencies. In particular, this demonstrates its positive results in improving its descriptive skills through practical training in the performance of tasks with a clear purpose, Baymetov \&
Sharipjonov[15]. The current practices and admission requirements for students wishing to enroll in the STVEP curricula, such as interviews and written exams, must be maintained to assess the fitness of students in the chosen curricula, I.Q., the level of interest, the understanding of 'learning by doing' and the potential objectives that may be achieved by obtaining the required technical knowledge, and skills.

\section{Appendix}

\section{TRAINING GUIDE IN TECHNICAL DRAWING 1 \& 2}

(Adapted from DepEd STVEP Competency-Based Curriculum)

\section{General Objectives}

Through the given instruction, demonstration, and thorough guidance, the students shall be able to:

1. Harness the power of visualization and keen observation;

2. Strengthen constructive imagination;

3. Enhance analytical and critical skills;

4. Hone accuracy of thought and expression;

5. Advance writing and reading skills towards the Language of Industry;

6. Develop the habits of neatness, orderliness, accuracy, cleanliness, speed, creativity, and resourcefulness;

7. Maintains the practice of good quality and design;

8. Interpret working drawing and specifications concerning Technical Drawing;

9. Sharpen the ability to apply the art and drawing principles; and techniques in one's work, in school, in industry, at home, and in everyday life; and

10. Appreciate Technical Drawing as a subject and all its undertakings.

Time Duration: 200 Hours for One School Year

Description: This Course Is Designed To Enhance The Knowledge, Desirable Attitudes, And Skills Of Students. It Covers Core Competencies Such Freehand Drawing, Lettering, Mensuration, Constructing Geometrical Figures, Orthographic Projection and Construct Pictorial Drawing. 


\begin{tabular}{|c|c|c|}
\hline COMPETENCY & UNITS OF COMPETENCY & NO. OF HOURS \\
\hline $\begin{array}{l}\text { Mensuration } \\
\text { Grade } 7\end{array}$ & $\begin{array}{l}\text { 1. Measure Object/Distance In millimeter } \\
\text { 2. Measure Object/Distance In centimeter } \\
\text { 3. Measure Object Distance In Inch } \\
\text { 4. Write Measurement On Drawing } \\
\text { 5. Secure Required Measuring Tool (Ruler) }\end{array}$ & $\begin{array}{l}20 \text { Hours or } 20 \\
\text { Meetings }\end{array}$ \\
\hline $\begin{array}{c}\text { Freehand Drawing } \\
\text { Grade } 7\end{array}$ & $\begin{array}{l}\text { 1. Draw Short And Long Horizontal Lines } \\
\text { 2. Draw Short And Long Vertical Lines } \\
\text { 3. Draw Short And Long Incline Lines } \\
\text { 4. Draw Short And Long Perpendicular Lines } \\
\text { 5. Draw Short And Long Parallel Lines } \\
\text { 6. Draw Arcs And Circles } \\
\text { 7. Draw Borderline } \\
\text { 8. Draw Objects In Outline Form } \\
\text { 9. Sharpen Pencil } \\
\text { 10. Erase Pencil Lines }\end{array}$ & $\begin{array}{l}20 \text { Hours or } 20 \\
\text { Meetings }\end{array}$ \\
\hline $\begin{array}{l}\text { Lettering } \\
\text { Grade } 7\end{array}$ & $\begin{array}{l}\text { 1. Draw Guidelines } \\
\text { 2. Print Lowercase Single-Stroke Gothic Letters } \\
\text { 3. Print Uppercase Single- Stroke Gothic Letters } \\
\text { 4. Print Single-Stroke Gothic Numbers and ampersand } \\
\text { 5. Print Words In Single-Stroke Gothic Letters } \\
\text { 6. Print Paragraphs In Sing-Stroke Gothic Letters } \\
\text { 7. Center Title Using "Trial-And-Error Method" } \\
\text { 8. Center Title Using "Scratch-Paper Method" } \\
\text { 9. Maintain Inter Letter Spacing } \\
\text { 10. Maintain Inter Word Spacing } \\
\end{array}$ & $\begin{array}{l}20 \text { Hours or } 20 \\
\text { Meetings }\end{array}$ \\
\hline $\begin{array}{c}\text { Construct Geometrical } \\
\text { Figures } \\
\text { Grade } 7\end{array}$ & $\begin{array}{l}\text { 1. Bisect Horizontal And Vertical Lines } \\
\text { 2. Bisect Arcs } \\
\text { 3. Bisect Common Angles } \\
\text { 4. Draw Equilateral Triangle } \\
\text { 5. Draw Square } \\
\text { 6. Draw Pentagon } \\
\text { 7. Draw Hexagon } \\
\text { 8. Draw Heptagon } \\
\text { 9. Draw Octagon } \\
\text { 10. Draw Nonagon } \\
\text { 11. Draw Decagon } \\
\text { 12. Draw Ellipse } \\
\text { 13. Manipulate Compass } \\
\text { 14. Manipulate Protractor } \\
\text { 15. Manipulate 30x60 And } 45 \times 45 \text { Triangles }\end{array}$ & $\begin{array}{l}30 \text { Hours or } 30 \\
\text { Meetings }\end{array}$ \\
\hline $\begin{array}{c}\text { Orthographic Projection } \\
\text { Grade } 8\end{array}$ & $\begin{array}{l}\text { 1. Sketch Alphabet Of Lines } \\
\text { 2. Block-In Views } \\
\text { 3. Draw Orthographic Views Of The Object With Horizontal and Vertical Surfaces } \\
\text { 4. Draw Orthographic Views Of Object With Inclined Surfaces } \\
\text { 5. Draw Orthographic Views Of Object With Regular Curved Surfaces. } \\
\text { 6. Draw Orthographic Views From The Given Pictorial View } \\
\text { 7.Draw A Detailed Working Sketch } \\
\text { 8. Sketch An Assembly Working Drawing } \\
\text { 9. Write Measurement On Top, Front, And Side Views Of An Object } \\
\text { 10. Manipulate Pencil And 45x45 Triangle }\end{array}$ & $\begin{array}{l}50 \text { Hours/ } \\
\text { Meetings }\end{array}$ \\
\hline $\begin{array}{l}\text { Construct Pictorial Drawing } \\
\text { Grade } 8\end{array}$ & $\begin{array}{l}\text { 1. Draw Isometric Axes } \\
\text { 2. Draw Isometric Views Of Objects With Horizontal And Vertical Surfaces } \\
\text { 3 Draw Isometric Views Of Object With Incline Surfaces. } \\
\text { 4. Draw Isometric Views Of Objects With Regular Curved Surfaces } \\
\text { 5.Draw Isometric View From The Given Orthographic Views } \\
\text { 6. Draw Cavalier And Cabinet Axes } \\
\text { 7. Draw Cavalier Pictorial Views } \\
\text { 8. Draw Cabinet Pictorial Views } \\
\text { 9. Draw Parallel Perspective. } \\
\text { 10.Draw Angular Perspective }\end{array}$ & $\begin{array}{l}50 \text { Hours or } 50 \\
\text { Meetings }\end{array}$ \\
\hline
\end{tabular}

Teaching Methodologies:

1. Mastery learning

2. Illustrative Demonstration

3. Lecture/discussion

4. Research, others

Assessment methods:

A. Written (Summative / Periodical) test 
B. Plate-making

C. Performance / Practical test

Facilities/equipment, tools, and materials

A. Drawing table - 18" x20" x34"

B. Drawing stool

C. Ruler

D. Sharpener

E. Triangles (30x60, 45x45) - 10 inches

F. T-square -24 inches

G. Compass

H. Protractor

I. Pencil (ordinary/mechanical)

J. Soft White Eraser

K. Masking Tape

L. Oslo paper -9" x12"

Learning resource materials:
A. Illustrated charts
B. Drafting books
C. Other related references
D. Printed materials

\section{Station: Naga National High School}

\section{Subject: Technical Drawing 1}

\section{Competency: Mensuration}
A. Unit Title: Measuring
B. Learning Objectives:
Through A Given Illustrative Discussion, The Students Shall Be Able To;
A. Define Measuring;
B. Identify The 2 Systems Of Measurement;
D. State The Importance Of Measurement; \&
E. Practice Measuring Using Ruler.

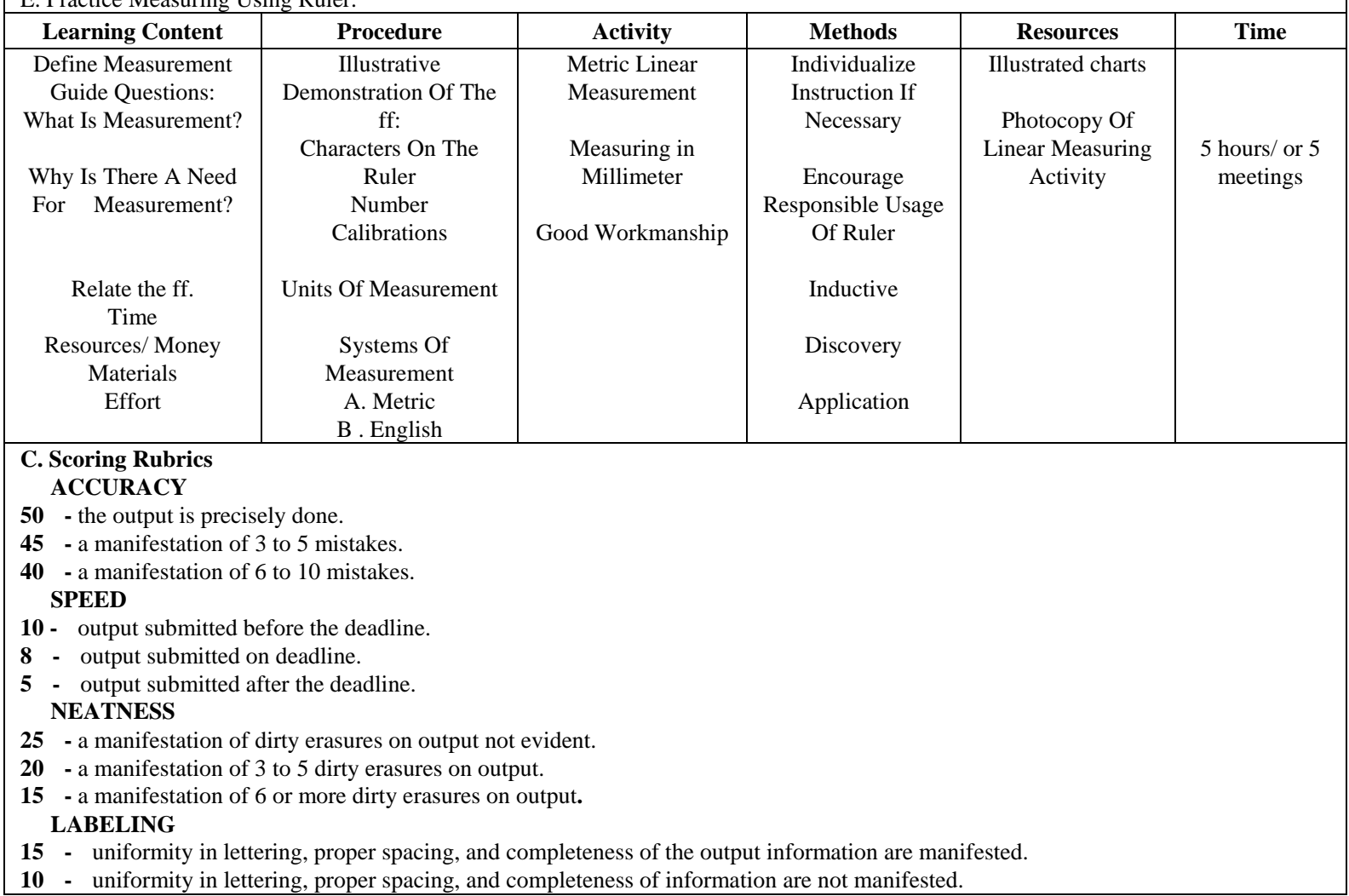




\section{Station: Naga National High School}

\section{Subject: Technical Drawing 1}

\section{Competency: Freehand Drawing}

\begin{tabular}{|c|c|c|c|c|c|}
\hline \multicolumn{6}{|c|}{ A. Unit Title: Title Block Making (Plotting Of Lines) } \\
\hline \multicolumn{6}{|c|}{$\begin{array}{l}\text { B. Learning Objectives: } \\
\text { Through a given illustrative discussion, the students shall be able to; } \\
\text { A. Define line; } \\
\text { B. Know the different types of line; } \\
\text { C. Understand the purpose of each line as a component in the title block; } \\
\text { D. Plot correctly the lines on the drawing paper; \& } \\
\text { E. Apply the proper technique of measuring. }\end{array}$} \\
\hline $\begin{array}{c}\text { Learning } \\
\text { content }\end{array}$ & Procedure & Activity & Methods & Resources & Time \\
\hline $\begin{array}{c}\text { Title } \\
\text { block-making } \\
\text { (plotting of lines) } \\
\text { Types of line } \\
\text { Horizontal line } \\
\text { Vertical lines } \\
\text { Incline lines } \\
\text { Purpose of the } \\
\text { line in title block } \\
\text { as: } \\
\text { Borderline } \\
\text { Visible line. } \\
\text { Guideline } \\
\text { Line projection } \\
\text { technique } \\
\text { Dot method } \\
\text { Center to center } \\
\text { method }\end{array}$ & $\begin{array}{l}\text { Discuss \& illustrate the } \\
\text { following:: } \\
\text { A. Definition of line } \\
\text { B. Types of line } \\
\text { C. Application of the types } \\
\text { of line to title } \\
\text { block-making using it as : } \\
\text { Borderline } \\
\text { Visible line } \\
\text { Guideline } \\
\text { Define and illustrate the } \\
\text { function of each in the title } \\
\text { block. } \\
\text { Integrate the techniques of } \\
\text { line projection, such as: } \\
\text { Dot method } \\
\text { Center to center method }\end{array}$ & $\begin{array}{c}\text { Defining } \\
\text { Brainstorming } \\
\text { Question-and answer } \\
\text { Drawing } \\
\text { Measuring } \\
\text { Good Workmanship }\end{array}$ & $\begin{array}{l}\text { Discussion } \\
\text { Demonstration } \\
\text { Discovery } \\
\text { Application }\end{array}$ & $\begin{array}{c}\text { Illustrated charts } \\
\text { Powerpoint } \\
\text { presentation }\end{array}$ & $\begin{array}{c}5 \text { hours/ or } 5 \\
\text { meetings }\end{array}$ \\
\hline $\begin{array}{l}\text { C. Scoring Rubric } \\
\text { ACCURACY } \\
50 \text { - output exactl } \\
45 \text { - a manifestati } \\
40 \text { - a manifestati } \\
\text { SPEED } \\
10 \text { - output submi } \\
8 \text { - output subm } \\
5 \text { - output subm } \\
\text { NEATNESS } \\
25 \text { - a manifesta } \\
20 \text { - a manifesta } \\
15 \text { - a manifesta } \\
\text { LABELING } \\
15 \text { - uniformity } \\
10 \text { - uniformity }\end{array}$ & $\begin{array}{l}\text { done. } \\
\text { of } 3 \text { to } 5 \text { mistakes. } \\
\text { of } 6 \text { to } 10 \text { mistakes. } \\
\text { ted before the deadline. } \\
\text { ted on the deadline. } \\
\text { ted after the deadline. } \\
\text { on of dirty erasures on outpu } \\
\text { on of } 3 \text { to } 5 \text { dirty erasures on } \\
\text { on of } 6 \text { or more dirty erasure } \\
\text { lettering, proper spacing, an } \\
\text { lettering, proper spacing, an }\end{array}$ & $\begin{array}{l}\text { not evident. } \\
\text { he output. } \\
\text { on the output. } \\
\text { completeness of the ou } \\
\text { completeness of inform }\end{array}$ & $\begin{array}{l}\text { nformation manif } \\
\text { is not manifeste }\end{array}$ & & \\
\hline
\end{tabular}




\section{Station: Naga National High School}

\section{Subject: Technical Drawing 1}

\section{Competency: Lettering}

\begin{tabular}{|c|c|c|c|c|c|}
\hline \multicolumn{6}{|c|}{$\begin{array}{l}\text { B. Learning Objectives: } \\
\text { Through a given illustrative discussion, the students shall be able to; } \\
\text { A. Review the techniques in plotting measurement; } \\
\text { B. Show the correct projection of visible lines and guidelines; \& } \\
\text { C. Describe single-stroke gothic letters } \\
\text { D. Apply proper lettering for DepEd's mission. }\end{array}$} \\
\hline $\begin{array}{c}\text { Learning } \\
\text { content }\end{array}$ & Procedure & Activity & Methods & Resources & Time \\
\hline $\begin{array}{c}\text { A. Lettering } \\
\text { "Deped mission." } \\
\text { Or } \\
\text { "City of Naga } \\
\text { Hymn" }\end{array}$ & $\begin{array}{l}\text { A. Show the content of } \\
\text { the activity to the } \\
\text { students } \\
\text { B. Illustrate the relative } \\
\text { measurement for: } \\
\text { 1. Distances } \\
\text { 2. Line of letters } \\
\text { 3. Lettering space }\end{array}$ & $\begin{array}{c}\text { Perform Measuring } \\
\text { Lettering } \\
\text { Visualizing } \\
\text { Good Workmanship }\end{array}$ & $\begin{array}{c}\text { Discussion } \\
\text { Demonstration } \\
\text { Discovery } \\
\text { Application }\end{array}$ & $\begin{array}{c}\text { Illustrated charts } \\
\text { Powerpoint } \\
\text { presentation }\end{array}$ & $\begin{array}{l}5 \text { hours/ or } 5 \\
\text { meetings }\end{array}$ \\
\hline \multicolumn{6}{|c|}{ C. Scoring Rubrics } \\
\hline \multicolumn{6}{|c|}{ ACCURACY } \\
\hline \multicolumn{6}{|c|}{50 - the output is precisely done. } \\
\hline \multicolumn{6}{|c|}{45 - a manifestation of 3 to 5 mistakes. } \\
\hline \multicolumn{6}{|c|}{40 - a manifestation of 6 to 10 mistakes. } \\
\hline \multicolumn{6}{|c|}{ SPEED } \\
\hline \multicolumn{6}{|c|}{10 - output submitted before the deadline. } \\
\hline \multicolumn{6}{|c|}{8 - output submitted on the deadline. } \\
\hline \multicolumn{6}{|c|}{5 - output submitted after the deadline. } \\
\hline \multicolumn{6}{|c|}{ NEATNESS } \\
\hline \multicolumn{6}{|c|}{25 - a manifestation of dirty erasures on output not evident. } \\
\hline \multicolumn{6}{|c|}{20 - a manifestation of 3 to 5 dirty erasures on output. } \\
\hline \multicolumn{6}{|c|}{$\begin{array}{l}15 \text { - a manifestation of } 6 \text { or more dirty erasures on output. } \\
\text { LABELING }\end{array}$} \\
\hline 15 - uniformity & lettering, proper spacing, & ad completeness of ou & tingre not mar & & \\
\hline
\end{tabular}




\section{Station: Naga National High School}

\section{Subject: Technical Drawing 1}

\section{Competency: Construct Geometrical Figures}

\begin{tabular}{|c|c|c|c|c|c|}
\hline \multicolumn{6}{|c|}{ A. Unit Title: Drawing Geometrical Figures } \\
\hline \multicolumn{6}{|c|}{$\begin{array}{l}\text { B. Learning Objectives: } \\
\text { Through a given illustrative discussion, the students shall be able to: } \\
\text { A. Interpret specification is given according to the required measurement; } \\
\text { B. Manipulate compass and other drawing instruments properly; } \\
\text { C. Bisect line, arc, and angle and draw parallelograms, and regular polygons;\& } \\
\text { D. Present a neat and accurate drawing output. }\end{array}$} \\
\hline Learning Content & Procedure & Activity & Methods & Resources & Time \\
\hline $\begin{array}{l}\text { Geometric Figures } \\
\text { a. Bisect line } \\
\text { b. Bisect Arc } \\
\text { c. Bisect angle } \\
\text { d. Draw equilateral } \\
\text { triangle } \\
\text { e. Draw parallelograms } \\
\text { 1. inscribe and } \\
\text { circumscribe squared } \\
\text { 2. Draw pentagon } \\
\text { 3. Draw hexagon } \\
\text { 4. Draw heptagon } \\
\text { 5. Draw octagon } \\
\text { 6. Draw nonagon } \\
\text { 7. Draw decagon } \\
\text { 8. Draw ellipse }\end{array}$ & $\begin{array}{c}\text { Part } 1 \\
\text { Discuss the usage of } \\
\text { the compass in the } \\
\text { process of bisecting } \\
\text { Explain specific } \\
\text { measure of } \\
\text { geometric figures } \\
\text { Part } 2 \\
\text { A. Bisect Line } \\
\text { Discuss the steps in } \\
\text { bisecting the line } \\
\text { B. Bisect Arc } \\
\text { Discuss the steps in } \\
\text { bisecting the arc } \\
\text { C. Bisect Angle } \\
\text { Discuss the steps in } \\
\text { bisecting the angle } \\
\text { D. Discuss the steps } \\
\text { in drawing the } \\
\text { regular polygons }\end{array}$ & $\begin{array}{l}\text { Upgrade skills in } \\
\text { measuring } \\
\text { Upgrade skills in } \\
\text { using measuring } \\
\text { instruments } \\
\text { Upgrade freehand } \\
\text { and lettering skills } \\
\text { Practice using } \\
\text { compass }\end{array}$ & $\begin{array}{c}\text { Illustrative discussion } \\
\text { Demonstration } \\
\text { Inductive } \\
\text { Application }\end{array}$ & $\begin{array}{c}\text { Illustrated charts } \\
\text { Powerpoint } \\
\text { presentation }\end{array}$ & $\begin{array}{c}5 \text { hours/ or } 5 \\
\text { meetings }\end{array}$ \\
\hline $\begin{array}{l}\text { C. Scoring Rubrics } \\
\text { ACCURACY } \\
50 \text { - the output is pre } \\
45 \text { - a manifestation } \\
40 \text { - a manifestation } \\
\text { SPEED } \\
10 \text { - output submitted } \\
8 \text { - output submitted } \\
5 \text { - output submitted } \\
\text { NEATNESS } \\
25 \text { - a manifestation o } \\
20 \text { - a manifestation o } \\
15 \text { - a manifestation o } \\
\text { LABELING } \\
15 \text { - uniformity in let } \\
10 \text { - uniformity in let }\end{array}$ & $\begin{array}{l}\text { ely done. } \\
3 \text { to } 5 \text { mistakes. } \\
6 \text { to } 10 \text { mistakes. } \\
\text { fore the deadline. } \\
\text { deadline. } \\
\text { ter the deadline. } \\
\text { irty erasures on output } \\
\text { to } 5 \text { dirty erasures on } \\
\text { or more dirty erasures } \\
\text { ring, proper spacing, a } \\
\text { ring, proper spacing, a }\end{array}$ & $\begin{array}{l}\text { hot evident. } \\
\text { utput. } \\
\text { on output. } \\
\text { d completeness of outp } \\
\text { d completeness of info }\end{array}$ & $\begin{array}{l}\text { ut information are manife } \\
\text { mation are not manifeste }\end{array}$ & & \\
\hline
\end{tabular}




\section{Station: Naga National High School}

\section{Subject: Technical Drawing 2}

\section{Competency: Orthographic Projection}

A. Unit Title: Orthographic Drawing

B. Learning Objectives:

Through a given illustrative discussion, the students shall be able to:

A. Define orthographic drawing;

B. Name the three fundamental views of orthographic drawing;

C. Draw orthographic project from a simple pictorial drawing;\&

D. Present a neat and accurate drawing output.

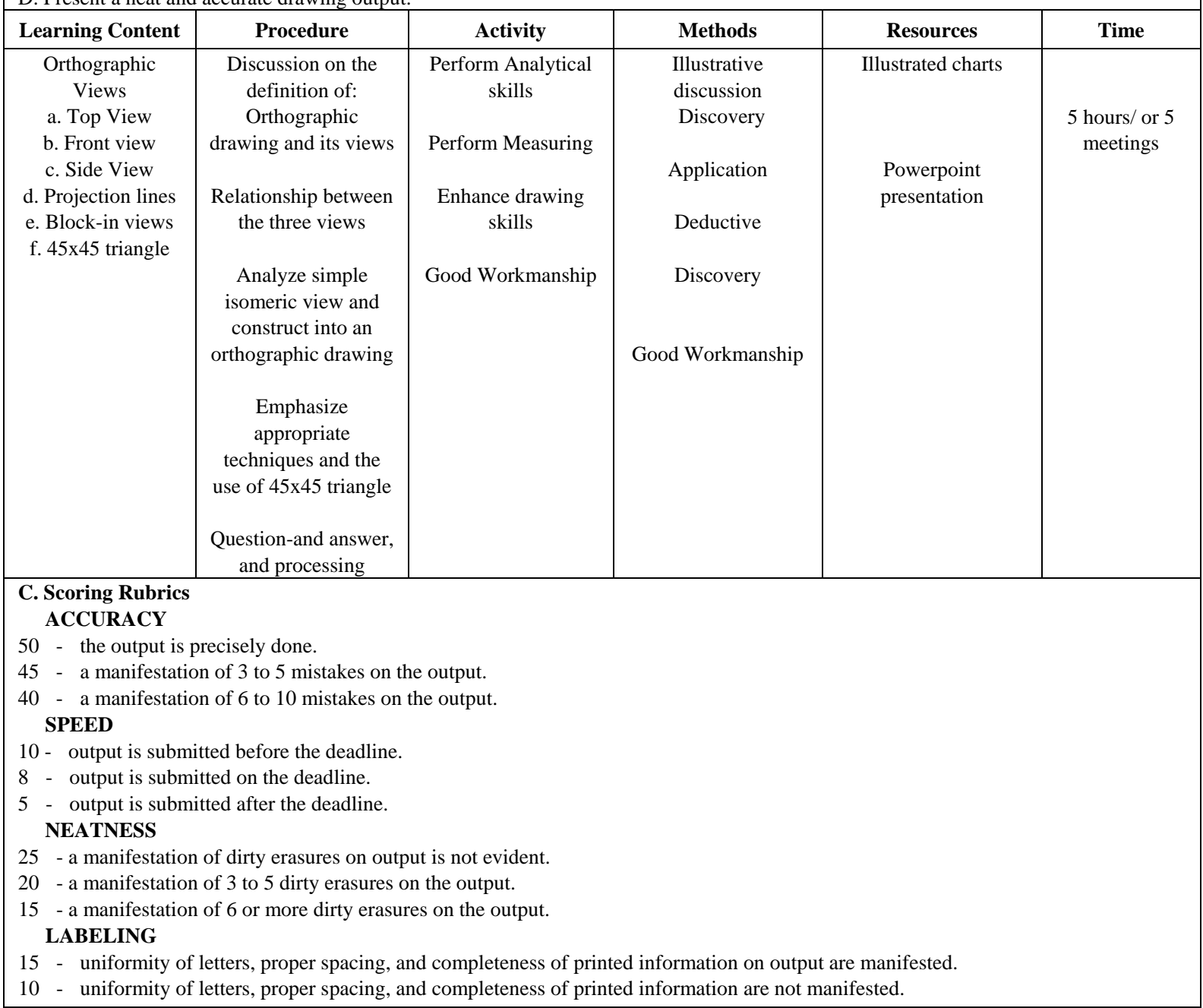




\section{Station: Naga National High School}

\section{Subject: Technical Drawing 2}

\section{Competency: Construct Pictorial Drawing}

A. Unit Title: Isometric Drawing

B. Learning Objectives:

Through a given illustrative discussion, the students shall be able to:

A. Define isometric view;

B. Differentiate isometric view from orthographic drawing;

C. Draw isometric view from a simple orthographic drawing; \&

D. Present a neat and accurate drawing output.

\begin{tabular}{|c|c|c|c|c|c|}
\hline $\begin{array}{c}\text { Learning } \\
\text { Content }\end{array}$ & Procedure & Activity & Methods & Resources & Time \\
\hline $\begin{array}{c}\text { Isometric view } \\
\text { Left-cross axis } \\
\text { Right-cross } \\
\text { axis } \\
\text { Vertical axis } \\
\text { Isometric box } \\
\text { 30x60 triangle }\end{array}$ & $\begin{array}{c}\text { Part } 1 \\
\text { Brief recall on } \\
\text { orthographic drawing } \\
\text { Let students } \\
\text { differentiate } \\
\text { orthographic drawing } \\
\text { from } \\
\text { isometric view } \\
\text { Part } 2 \\
\text { Discuss the ff. } \\
\text { Isometric view and its } \\
\text { axes } \\
\text { Isometric box } \\
\text { Synthesizing } \\
\text { orthographic drawing } \\
\text { to an isometric view } \\
\text { Steps and techniques } \\
\text { and the use of 30x60 } \\
\text { triangle } \\
\text { Question-and-answer } \\
\text { and processing }\end{array}$ & $\begin{array}{c}\text { Synthesizing } \\
\text { concepts of } \\
\text { orthographic to } \\
\text { isometric } \\
\text { Perform Measuring } \\
\text { Enhance drawing } \\
\text { skills } \\
\text { Good Workmanship }\end{array}$ & $\begin{array}{l}\text { Illustrative discussion } \\
\text { Demonstration }\end{array}$ & $\begin{array}{c}\text { Illustrated charts } \\
\text { Powerpoint } \\
\text { presentation }\end{array}$ & $\begin{array}{c}5 \text { hours/ or } 5 \\
\text { meetings }\end{array}$ \\
\hline $\begin{array}{l}\text { C. Scoring Rub } \\
\text { ACCURAC } \\
50 \text { - the outpl } \\
45 \text { - a manife } \\
40-\text { a manife } \\
\text { SPEED } \\
10 \text { - output is s } \\
8 \text { - output is s } \\
5 \text { - output is s } \\
\text { NEATNESS } \\
25 \text { - a manife } \\
20 \text { - a manife } \\
15 \text { - a manife } \\
\text { LABELING } \\
15 \text { - uniformi } \\
10-\text { uniformi }\end{array}$ & $\begin{array}{l}\text { cs } \\
\text { is precisely done. } \\
\text { tion of } 3 \text { to } 5 \text { mistakes } \\
\text { tion of } 6 \text { to } 10 \text { mistakes } \\
\text { mitted before the deadl } \\
\text { tion of dirty erasures or } \\
\text { tion of } 3 \text { to } 5 \text { dirty eras } \\
\text { of letter of } 6 \text { or more dirty } \\
\text { of letters, proper spacin }\end{array}$ & $\begin{array}{l}\text { the output. } \\
\text { n the output. } \\
\text { utput is not evident. } \\
\text { sures on output. } \\
\text { and completeness of } \\
\text { and completeness of }\end{array}$ & $\begin{array}{l}\text { ted information on out } \\
\text { ated information are no }\end{array}$ & $\begin{array}{l}\text { e manifested. } \\
\text { ifested. }\end{array}$ & \\
\hline
\end{tabular}




\section{REFERENCES}

[1] Wood, W. (2017). Habit in personality and social psychology. Personality and Social Psychology Review, 21(4), 389-403.

[2] Simons, D. (2010). Monkeying around with the Gorillas in Our Midst: Familiarity with an Inattentional-Blindness Task Does Not Improve the Detection of Unexpected Events, I-Perception, Vol.1 No.1, pp. 3-6.

[3] Singh, S. (2009). Biography of Edward L. Thorndike, Encyclopedia Britannica.

[4] Lyons, M. N., Green, R., Raiford, S., Tsemunhu, R., Pate, J., \& Baldy, T. (2013). The Relationship between Teacher Empowerment and School Performance. National Teacher Education Journal, 6(2).

[5] Kalule, S. W., Sseguya, H., Ongeng, D., \& Karubanga, G. (2019). Facilitating conditions for farmer learning behavior in the student-to-farmer university outreach. The Journal of Agricultural Education and Extension, 25(3), 211-225.

[6] Shulruf, B., Li, M., McKimm, J., \& Smith, M. (2012). Breadth of knowledge vs. grades: What best predicts achievement in the first year of health sciences programs?. Journal of Educational Evaluation for Health Professions, 9.

[7] Octavia, E. T. (2020). How Do School Facilities Affect School Quality? Case Study in Vocational High School at Pati, Indonesia. KnE Social Sciences, 865-881.

[8] Moses, K. M. (2016, October). Improving the quality and competence of technical vocational education and training output through vocational school cooperation with industry: A case study of Uganda. In AIP Conference Proceedings (Vol. 1778, No. 1, p. 030060). AIP Publishing LLC.

[9] Uddin, P. S., \& Nwachokor, S. C. (2019). Influence of Personality Trait of Teachers Teaching Technical Drawing in Technical Colleges in Edo and Delta States. Education Journal, 8(3), 120-124.

[10] Sira, K. S. (2016). Development and Validation of Standard Competencies in Architectural Drafting Technology
Program. The Normal Lights, 10(2).

[11] Sira, K. S., Celda, M. A. M., Valenciana, D. S. O., \& Sobrepe $\tilde{A} \pm a$, A. C. (2018). The Bachelor of Industrial Technology Major in Architectural Drafting Technology Program Tracer Study. The Normal Lights, 12(2).

[12] Avila, M. R. M., \& Malquisto, P. R. (2019). Gender Disparity Competence in Drafting Technology among Government Secondary Learning Institutions. European Scientific Journal, 15(5), 196-214.

[13] Goetsch, D. L., Chalk, W., \& Nelson, J. A. (2000). Technical drawing. Cengage Learning.

[14] Adanez, G. P., \& Velasco, A. D. (2004). Training visualization ability by technical drawing. Journal for Geometry and Graphics, 8(1), 107-115.

[15] Baymetov, B. B., \& Sharipjonov, M. S. O. (2020). Development Of Students' Descriptive Competencies In Pencil Drawing Practice. The American Journal of Social Science and Education Innovations, 2(08), 261-267.

[16] Azodo, A. P. (2016). Attitude of engineering students towards engineering drawing: A case study. Int. J. Res. Studies in Edu, 6(1), 71-84.

[17] Oanh, D. T. K. (2019). Integrating Competence-Based Assessment into Instruction Pedagogical Subjects for Developing Core Competencies of Technical and Vocational Education Students at Ho Chi Minh City University of Technology and Education. Universal Journal of Educational Research 7(10): 2045-2056

[18] Omar, M. K., Zahar, F. N., \& Rashid, A. M. (2020). Knowledge, Skills, and Attitudes as Predictors in Determining Teachers' Competency in Malaysian TVET Institutions. Universal Journal of Educational Research 8(3C): 95-104

[19] https://www.teacherph.com/deped- grading-system/

[20] https://www.deped.gov.ph/wp-content/uploads/2019/01/Tec hnical- Drafting-NC-II-

[21] https://www.coursehero.com/file/38553228/k-to-12-mechan ical-drafting-learning- module pdf/

[22] https://dlrciligan.weebly.com/uploads/5/0/8/0/50800379/me chanical_drafting_tg.pdf 